\title{
Jack Mezirow's conceptualisation of adult transformative learning: A review
}

\author{
Colin Calleja \\ University of Malta
}

Email: colin.calleja@um.edu.mt

\begin{abstract}
This paper traces the evolution of Jack Mezirow's transformative learning theory and its conceptualisation. It discusses the three major influences, namely Thomas Khun's philosophical conception of paradigm, Freire's conception of conscientisation and consciousness growth, and Habermas' domains of learning and the discussion of language as communicative action. The paper concludes with a discussion of the main concepts underlying the theory of transformative learning - a theory grounded in robust theoretical traditions - and presents a process of transformation which leads the adult learner through a process that initiates in a moment of disorientation and ends in transformative self-reflection that results in the transformation of one's perspective.
\end{abstract}

\section{Keywords}

transformative learning; adult learning; Jack Mezirow; professional learning; perspective transformation

\section{Introduction}

For the past 15 years I have been working in teacher training and continuous professional development and have always been intrigued with how teachers transform their practice. Tracking Jack Mezirow's extensive contribution to the understanding of adult transformative learning experience helps one under. stand the deep, structured shift experienced by individuals who allow thernselves to learn from their own experience within a community of practice. This paper forms part of a larger work that tracks the transformative experience of nine educators in a confessional school on the island of Malta. This school has participated in a professional development programme coordinated by the author and 
has reported a significant change of practice. What follows is a discussion of the literature that informed the research methodology and analysis of this reported transformation of practice.

\section{Methodology}

Identifying the literature for this review involved searching for literature through multiple sources and strategies. It involved searching different databases Proquest, Googlescholar, Sage, ERIC and ISTOR - using several criteria (mainly keywords and author's name). The keywords used are: transformative learning, systematic change, perspective transformation, adult learning, professional development, professional learning, adult education, teacher education, self-knowledge, reflection and reflective practice. Other strategies were employed such as searching through reference lists of reviewed papers and books (reference chaining) and citation search, that is, following references cited in key reviewed works.

The data generated froin the literature reviewed was ordered, coded and categorised according to the main data groups and subgroups utilising a theoretical framework spreadsheet to help organise the themes and subthemes generated for this research.

\section{Transformative learning: Jack Mezirow's conceptualisation}

Transformative learning is 'a deep, structural shifi in basic premises of thought, feelings, and actions' (Transformative Learning Centre, 2004). However, this defirition belies the fact that this type of learning is complex and multifaceted (Kitchenham, 2008).

Jack Mezirow's theory of transformative learning has, over the past three decades, changed the way we understand adult learning and by consequence how we do pedagogy for adults, often referred to as andragogy (Knowles, 1998). Jack. Mezirow has led this movement of transformative leaming with almost every article, journal, or book published on transformation and adult learning citing him. He has restated the position transformative learning holds within the learning process (Caswell, 2007; Taylor, 2000a).

A key notion pervading literature on adult learning is the role of experience and prior learning (Belzer, 2004; Burke \& VanKleef, 1997; Challis, 1996; Romaniuk \& Fern, 2000). Literature explores ways in which prior experience in formal learning contexts influences adult learners' views of their current context. Others problematise this notion and go beyond just content knowledge acquisition, attempting to understand the conditions required to transform learning through emphasis on contextual understanding, critical reflection on assumptions and validated meaning by assessing reasons (Boud, Keough, \&Walker, 1985; Boyd, 1989; Boyd and Myers, 1988; Brookfield, 1987; Freire, 1970; Kitchener \& King, 1990; Marsick and Mezirow, 2002; Mezirow, 1991 and 1997; Mezirow \& Associates, 1990 and 2000). 
Mezirow's original study, which focused on the change in perspective experienced by women returning to formal education after a long break from school, made some revealing insights on how we understand learning in adulthood and the role of prior learning. Learning, according to Mezirow (1996) was 'understood as the process of using a prior interpretation to construe a new or revised interpretation of the meaning of one's experience in order to guide future action', We accomplish this meaning making by 'projecting images and symbolic models, meaning schermes based upon prior learning, onto our sensory experiences and imaginatively use analogies to interpret new experiences' (Mezirow; 1996). As can be appreciated, such insight has particular relevance to teacher education. Acculturalisation of teachers within the profession can only take place when they becorne aware of the knowledge, influences and hidden theories accrued over the years.

Mezirow's rendering of transformative learning emphasised the importance and centrality of experience, understanding one's frame of reference, the role of disorienting dilemma, the importance of critical reflection and critical selfreflection, the role of rational discourse, and of dialogue in communicating with others. In his work he also amply discusses the conditions that foster such transformation. A discussion of these concepts would reveal 'a picture of transfarmative learning theory that is much more complex and multifaceted than originally understood' (Taylor, 2000a).

Transformative learning theory is about becoming aware of one's own and others' tacit assumptions and expectations, and assessing their relevance for making an interpretation (Mezirow, 2000). Mezirow appropriates James Loder's five steps for transformative logic and reorganises them to explain that, "comprehension involves a conflich, scanning, and construal, during the latter of which a constructive act of imagination occurs, resulting in an interpretation' (Mezirow \& Associates, 2000).

Early on, Mezirow emphasised the social dimension of transformative learning and showed the inportance of interacting with others 'to identify alternative perspectives, to provide emotional support during the process of transformation, to analyse one's own interpretation of one's situation from different points of view, to identify one's dilemma as a shared and negotiable experience ... and to provide models for functioning within the new perspective' (Mezirow \& Associates, 1990). In his response to Collard and Law (1989) in which they criticised him for his lack of emphasis on collective social action, Mezirow (1989) explains that, while social action is crucial and desirable, the decision regarding such involvement is that of the learner, not the educator. The role of the educator, if it is agreeable with one's values, is to support and help learners in their quest through helping them 'research, plan tactics and develop the skills required for appropriate action to overcome constraints in these areas' (Mezirowr, 1989). Thus Mezirow in his theory emphasises the learner's free will in closing the cycle of transformation by reintegrating the new perspective into life and acting it in the social dimension. Cranton (2013) explains the distinction made by Mezirow between the goal of helping individuals "become aware of oppressive structures and change them, and the 
political goal of forcing economic change'. This important distinction brings forth the complementary nature of the two sides of transformative learning, namely the need for individuals to transform themselves through awareness of the limiting structures leading to praxis, which in turn can lead some to join 'political' forces to bring about a change in the world in which they live. Thus, contrary to the concept of 'learning organisations', popularised by Senge, organisations, according to Cranton (2013) do not learn but may change through the transformative learning experienced by the individuals who form part of the organisation.

Merriam and Caffarella (1999) define transformative learning as change, 'dramatic, fundamental change in the way we see ourselves and the world in which we live.' Clark (1993b) contends that such learning shapes people; they are different afterwards, in ways both they and others can recognise. Thus, through critical reflection, engagement in discourse, and reflectively and critically taking action on the transformed frame of reference (Marsick \& Mezirow, 2002), learners proceed to new ways of perceiving, thinking, deciding, feeling and acting on their experience (Mezirow \& Associates, 1990). Calleja and Borg (2014) report on how a group of educators participating in a professional learning process (the Let Me Learn professional learning process) were helped to self-examine their intentions through a mentoring process. Through mentoring, the educators reflected on their practice and entered in a dialogic communication with their mentor about their practice. This dialogic communication helped participants reflect on the realities of their practice in light of their new understandings. These educators make reference to the process of mentoring and training as one that respected the pace and curiosities of the participants, allowing space for reflection and praxis.

\section{Influences}

Mezirow's theory of transformative learning has been influenced and inspired by a number of important thinkers. With such classical contributions by Thomas Khun, Paolo Freire and Jurgen Habermas, Mezirow could lay the foundation for a robust theory of transformative learning (Mezirow, 1991a).

This review will give a brief outline of the three early and most important influences on Mezirow's work that helped form the basic facets related to his theory. These include Kuhn's (1962) philosophical conception of paradigm, Freire's (1970) conception of 'conscientisation', and Habermas' (1971; 1984) domains of learning and the discussion of language as communicative action.

\section{Thomns Somuel Kuhn}

Kuhn's paradigmatic transformations in scientific knowledge (1962) provided a basis for Mezirow's notion of transformative learning. Kuhn uses paradigm to refer 'to a collection of ways of seeing, methods of inquiry, beliefs, ideas, values, and attitudes that influence the conduct of scientific inquiry' (Mezirow, 1991a). This came about as a result of Kuhn's realisation that among the social scientists and the natural scientists there was a major disagreement as to what constituted a 
legitimate scientific inquiry (Kitchenham, 2008; Mezirow, 1991b). In the process of this investigation Kuhn came up with the concept of paradigm, which Kisiel (1982, cited in Mezirow, 1991a) characterises as that which we look through rather then look at in viewing the world'. Mezirow defines it as 'an articulated, theory-based, collectively held meaning perspective' (Mezirow, 1991a). Others have subsequently used other terms to refer to the same concept: model, conceptual framework, approach, and worldview are synonyms to what Mezirow identifies as a paradigm. Such paradigms would have a basis in comprehensive theories, which generate new vocabularies that can then serve the function of cognitive filters.

According to Kuhn (1962), a true paradigm would include a shared set of problems and solutions, a differentiated perusal of interests and a shared common worldview (Kitchenkam, 2008).

Erving Goffman (1974, cited in Mexirow, 1991a) referred to a shared worldview or 'definition of a situation that organizes and governs social interaction' (Mezirow, 1991a) as a frame. 'A frame,' continues Mezirow, 'tell[s] us the context of a social situation and how to understand and behave in it. Frannes are therefore similar to Kulin's paradigm, in that frames also hold a shared common worldview but, unlike Kuhn's paradigm, frames are tacit, that is, unconscious filters which form the 'boundary structures' for perceiving and comprehending (Mezirow, 1991a). This is similar to Argyris and Schön's (1974) mental maps, which stir and direct one's actions (theorjes-in-use), often without the actor's conscious and explicit will. Tacit memory is 'culturally assimilated habits of expectation that allow us to scan and censor the experienoe of our senses' (Mezirow, 1991a).

In Mezirow's theory (1985; 1991a; Mezirow \& Associates, 2000), paradigm became the frame of reference. A frame of reference comprises habits of the mind and meaning perspectives, which in turn lead to a perspective transformation by making explicit the message system that enables us to reformulate a constraining frame of reference (Bowers, 1984).

Perspective transformation alters meaning structures (fraines of reference) that adults have acquired over a lifetime through their individual cultural and contextual experiences. Such deeply ingrained experiences influence how an individual behaves and interprets events (Tayfor, 1998, cited in Imel, 1998).

\section{Paolo Ereire}

The Brazilian educator and influential theorist of critical pedagogy, Paolo Freire, is another major influence in Mezirow's transformative learning theory, especially in the initial stages of its development. A major concept, which Mezirow takes on board, from Freire's critical pedagogy, is conscientisation. In Freire (1970) 'conscientizaçso' or conscientisation is defuned as 'learning to perceive social, political, and economic contradictions - dereloping a critical awareness - so that individuals can take action against the oppressive elements of reality. Freire argued for a transformative relationship between all the actors in a learning environment. Such a transformative relationship is difficult, argued Freire, because teachers 
themselves have a difficult time getting past the "instilled certainty" that teaching is a unidirectional activity in whith teachers 'bank knowledge without inyolving students in a critical and dialogic relationship with this knowledge (Freire, 1974).

A democratic relationship allows space both for the teacher to present critical ideas for discussion and for input from the students, thus 'affirm [ing] themselves [the teachers] without thereby disaffirming their students' (Freire \& Faundez, 1989). The lifeline for this democracy is conscientisation and its related critical consciousness, which Freire argues is actualised through three stages of consciousness growth (Freire, 1974).

The first and lowest stage is what Freire termed as intransitive thought - a level in which individuals feel disempowered to bring about change in their condition because all is pre-destined by fate. While the second level, semitransitive, inyolves some thought and action for change, it still addresses one problem at a time, as they occur, without seeing the organic nature of the problem, as one involving the whole of society. The highest level or stage of consciousness, which is the one that mainly influenced Mezirow in his notion of disorienting dilemma, is critical transitivity. Contrary to naive transitivity, critical transitivity is a deep explanation of causal principles that lead to the practice of dialogue built on sound argumentation (Freire, 1974). Thus critical transitivity is characterised by critical reflection, critical self-reflection on assumptions, and critical discourse (Mezirow, 1978a; $1978 \mathrm{~b} ; 1985$ ). According to Freire, this is achieved when individuals think globally and critically about a problem and are able to take action for bringing about critical change as a result of critical thought 'to affect change in their lives and to see what the catalyst for that change would be' (Kitchenham, 2008).

\section{Jürgen Habermas}

A major influence in Mezirow's theory is without doubt the work of jtirgen Habermas. What follows is a discussion of two aspects of Habermas' theory that had a major influence on Mezirow's transformative learning theory.

The sociolinguistic context

Mezirow (1991a) attributes the sociolinguistic context of transformative learning to Habermas, in particular through Habermas' seminal work, The Theory of Conmunicative Action (1984; 1987). According to Mezirow (199la) this work 'suggests a new foundation for understanding adult learning and the function and goals of adult education'. In his book Transformative Dimensions of Adult Learning, Mezirow (1991a) reviews this work under the subheadings "The sociolinguistic context of transformative learning' and 'The dynamics of communicative action.' He then moves on to summarise Habermas' other contribution Knowledge and Human Interest (1971) in which he expands on the three broad areas in which human interest generates knowledge (the three domains of learning which will be discussed further on in this analysis).

In the sociolinguistic context, Habermas refers to the applications of validity criteria as "grounding. According to Habermas (1984) "grounding" descriptive 
statements means establishing the existence of states of affairs', that is, when the conditions for understanding an utterance are established, and both the speaker and the hearer ${ }^{c}$ understand the meaning of a sentence [and] when they know under what conditions it is true' (Habermas, 1984). Once validity is established, true communicative action can take place and language takes a humanisation process.

For Habermas, the 'process of humanisation' is found in the use of language. Following George Herbert Mead's symbolic interactionism, Habermas sustains that the development of speech and self-consciousness are steadfastly bound to one another and are only possible in a social context' (Horster, 1992).

Therefore linguistic action, which is for Habermas the ultimate model of action, must be built on truth between actors, because if we assume that most people generally lie, then language would lose its mission, and communication would be inipossible (Habermas, 1984). For such understanding to take place and discourse to be made possible, validity claims need to be explicitly defined and any distortious cleared.

\section{The dynamics of communicative action}

Communicative action allows human beings to interact with the world around them, with other people, and with oneself (with one's intentions, feelings, and desires) and thus the validity of what is said, implied, or presupposed is of utmost importance for communication to persist and to allow meaning perspectives to affect the validation process and be transformed. The validation process initiates from the identification of a problem, through reflection, empirical or consensual validation, and imaginative insight to make a new interpretation. Throughout this process, meaning perspectives play an influencing role and when new interpretations are formed, transformation of meaning perspectives can occur (Mezirow, 1991a).

Rationality in Habermas is validity testing by reasoning - using reason for weighing evidence and supporting arguments. Habermas uses the term "argumentation' to refer to 'that process of dialogue in which implicit validity claims are made explicit and contested, with an effort to criticize and vindicate them through arguments' (Mezirow, 1991b). Mezirow continues, 'In the context of communicative action, the responsible and autonomous adult is one who is a member of a communication community that is able to participate fully in discourse devoted to assessing criticisable validity claims. In this excerpt Mezirow defines the role of the adult as a communicative being with the ability to validate and interpret arguments in a dialogic process, thus negotiating 'meanings and purposes instead of passively accepting the social realities defined by others' (Bowers, 1984).

In his discussion of the dynamics of communicative action, Habermas identifies three interrelated dynamics, namely the dynamics of the lifeworld, learning and social integration.

Habermas (1987, eited in Horster, 1992) defines 'lifeworld' (Lebenswelt, first used by Husserl) as follows: the lifeworld 'consists of individual skills, the intuitive 
knowledge of how one deals with a situation; and from socially acquired practices, the intuitive knowledge of what one can rely on in a situation, not less than, in a trivial sense, the underlying convictions'. Thus, Habermas furthers Husserl's definition, who beld that "views, intellectual spectrum and interest as the basis for perception of the world are located solely within the individual' (Horster, 1992), and ties into Mead's social argument. Mead emphasised that people are social beings and thus the importance of the social space of a commonly inhabited lifeworld that opens up in a conversation provides the key to the communicationtheoretical concept of society' (Habermas, Entgegnung, cited in Horster, 1992). Habermas claims:

Subjects acting communicatively always come to an understanding in the horizon of a lifeworld .... formed from more or less diffuse, always unproblematic, background convictions ... [it] serves as a source of situation definitions that are presupposed by participants as unproblematic ... The lifeworld also stores the interpretive work of preceding generations (Habermas, 1984).

Habermas also uses phrases like 'pre-reflective', a set of 'taken-for-granted background assumptions,' 'naively mastered skills,' and '[it] enters a tergo [literally, from behind] into cooperative processes of interpretation' (Habermas, 1984). He quotes Wittgenstein, who said that the 'certainties' present in one's worldview are 'so anchored that I cannot touch [them]' (Wittgenstein, 1969, quoted in Habermas, 1984).

Habermas builds on Mead's assertion that symbols (verbal, non-verbal and paraverbal) need to carry the same meaning for all participants in the interaction. Only when linguistic symbols are shared can real communication occur. Thus in Horster's words:

Social structures then develop through language because language contains that which is necessary to form the structure of a society and, correspondingly, to allow the functioning interaction of the members of the society: customs, cultural traditions, selfevident moral principles, technical skills (Horster, 1992).

Thus, for Mead, as for Habermas, language is the medium that draws all participants in the interaction into the communication community; it socialises the individuals and, at the same time, obliges the members to become individuals.

Mezirow (1991a) in his discussion of Habermas, furthers the discussion of the lifeworld as the symbolically pre-structured world which is a 'culturally transmitted and linguistically organised stock of interpretive patterns' (Habermas, 1984) or perspectives. It is the world that is made up of 'unquestioned assumptions and shared cultural convictions, including codes, norms, roles, social practices, psychological patterns of dealing with others, and individual skills' (Habermas, 1984). It is considered to be a foundation from which learners can start negotiating common definitions of situations. Habermas identifies three processes by which the lifeworld can be reproduced - cultural reproduction, social integration and socialisation - all of which have important links to the function of communicative action. 
This conception of the 'lifeworld' is an important reference to Mezirow's understanding of 'meaning schemes' and 'meaning perspectives'. He defines the former as habitual, implicit rules for interpreting the world; the latter refers to the 'structure of assumptions within which new experience is assimilated and transformed by one's past experience during the process of interpretation' (Mezirow, 1991a). Thus, through meaning perspectives, individuals interpret their experience of the lifeworld

Habermas' second dynamic of communicative action involves the transformative nature of the learning process, which for Habermas can be achieved through critical reflection. Only through critically reflecting on one's actions (communicative practice) is the power of the lifeworld diminished. Such critical reflection, suggests Habermas, is the process of validity testing - the process of dialogue in which 'contents can be challenged through argumentative discourse that raises questions of truth, justice, and self-deception respectively' (Mezirow, 19912). Habermas (1984) highlights four forms of discourse: explicative discourse, which is related to the well-formed and rule-correct symbolic expressions. The second type is theoretical aiscourse - this type has as its subject the knowledge we hold about the world that can be validated by empirical tests. Theoretical discourse is the most institutionalised and sophisticated, because it manifests itself in the development of scientific institutions and modes of argumentation (Lyytinent \& Hirschheims, 1988).

The third type of discourse - practical discourse - 'pertains to utterances that involve social norms, ideals, values, and moral decisions' (Mezirow, 1991b). According to Habermas, such discourse is a rigorous form of the argumentative development of an informed opinion that can guarantee the correctness of a normative consensus. In practical discourse, disputed norms only meet with approval if the rules of discourse are obeyed - that is, when consensus is achieved through rational dialogue. The fourth type of discourse - therapeutic discourse involves feelings or intent, both of which pertain to a person's subjectivity. Such speech acts can be challenged for their authenticity.

Habermas (1984) argues that it is through the manifestation of these four types of discourse that discursive action is realised and thus offers the possibility to transforn meaning schemes and perspectives (Mezirow, 1991b). Such discourse offers the possibility to critically reflect on the lifeworld and "decentre oneself away from an egocentric understanding of the world towards a progressive willingness and ability to participate in rational argument about the validity of what is communicated (Mezirow, 1991b).

Finally in the dynamics of communicative action, Habermas discusses the selfregulating system of society and social interaction. Society generates its lifeworld; some have limited and closed worldviews (traditional societies) and others (such as most modern cultures) offer more open viorldwiews with more possibility for their members to modify their meaning perspectives in the light of their experiences.

Habermas inakes a point on the need to develop the institutions that tend to promote narrowly focused worldviews, and the communicative competence of 
their members to secure an effective functioning of the public sphere in which critical discourse acts as the basis for achieved agreement. This ties nicely with Paolo Freire's concept of conscientizaçato, a requirement for self-affirmation.

This dynamic is crucial for a profession that tends to promote conformity - a barrier to fostering critical reflective dialogue among its members. Teachers are often looked at as technicians, whose lifeworld is 'colonized', leading 'to distortion of the rational decision making and adult learning processes' (Mezirow, 1991b).

\section{The domains of adult learning}

In his paper entitled 'A critical theory of adult learning and education', published in the journal Adult Education (1981) and later restated in his book Transformative Dimensions of Adult Learning, published in 1991, Mezirow discusses Habermas' conception of the three generic 'knowledge constitutive' domains of adult learning. Habermas identifies three domains that generate knowledge and determine categories and modes of discovering knowledge. They establish whether knowledge claims are warranted.

The three learning domains - the technical, the practical and the emancipatory - are grounded in different aspects of social existence: work, interaction and power respectively. Each would require fundamentally different methodologies of systematic objective enquiry (see Table 1 below):

The first type of human interest, according to Habermas, is the technical interest. This refers to the way one controls and manipulates one's environment ('work'). Such a cognitive domain requires instrumental action ('strategic' action) that is based upon empirically acquired knowledge and governed by technical rules. This form of learning is essentially about getting the skills and information necessary to construct systems and devise methods for making those systems work (Jesson \& Newman, 2004).

Instrumental action always involves prediction about observable events that can then be proved or disproved. Thus hypotheses are confirmed through a system monitoring feedback. The empirical-analytic sciences have been developed

Table 1: Habermas' three domains of knowledge (modified from Macisaac, 1996).

\begin{tabular}{|c|c|c|c|}
\hline $\begin{array}{l}\text { Type of human } \\
\text { interest }\end{array}$ & $\begin{array}{l}\text { Kind of } \\
\text { knowledge }\end{array}$ & $\begin{array}{l}\text { Aspects of social } \\
\text { existence }\end{array}$ & $\begin{array}{l}\text { Research } \\
\text { methods }\end{array}$ \\
\hline Technical & $\begin{array}{c}\text { Instrumental } \\
\text { (Casual explanation) }\end{array}$ & Work & $\begin{array}{l}\text { Empirical-analytic } \\
\text { methods }\end{array}$ \\
\hline Practical & $\begin{array}{c}\text { Practical } \\
\text { (Understanding) }\end{array}$ & Interaction & $\begin{array}{l}\text { Hermeneutic } \\
\text { Methods }\end{array}$ \\
\hline Emancipatory & $\begin{array}{l}\text { Emancipatory } \\
\text { (Reflection) }\end{array}$ & Power & $\begin{array}{l}\text { Critical theory } \\
\text { methods }\end{array}$ \\
\hline
\end{tabular}


expressly to assist us in understanding those interests that are related to work. Thus such interests are verified through an approach using hypothetical-deductive theories and permitting the deduction of empirical generalisations from hypothesis through controlled observation and experimentation.

The second cognitive interest is what Habermas calls 'practical'. This area of practical interest involves interaction or 'communicative action'. Communicative action:

is governed by binding consensual norms, which define reciprocal expectations about behaviour and which must be understood and recognized by at least two acting subjects. Social norms are enforced through sanctions. Their meaning is objectified in ordinary language communication. While the validity of technical rules and strategies depends on that of empirically true or analytically correct propositions, the validity of social norms is grounded only in the inter-subjectivity of the nutual understanding of intentions and secured by the general recognition of obligations (Habermas, 1971).

Communicative action has as its aim the clarification of conditions for communication and inter-subjectivity - 'systematic inquiry which seeks the understanding of meaning rather than to establish causality" (Mezirow, 1981).

Habermas concerns hinnself with the conditions under which universally valid claims might be expected to emerge. The first of these is that all nembers of a community are free to accept the proposed norms and procedures and must be rationally motivated, thus members must be free and un-coerced (Habermas, 1989-90).

A related condition is equality. This means that all participants have an equal voice in the discussion regarding proposed norms and procedure. In particular, consensus emerges here as a requirement - the un-coerced agreement of all who are affected by a proposed norm or procedure (Habermas, 1989-90).

Mezirow (1991b) explains that under these conditions, participants will:

- have accurate and complete information;

- be free from cocrcion and distorting self-deception;

- be able to weigh evidence and assess arguments objectively;

- be open to alternative perspectives;

- be able to become critically reflective upon presuppositions and their consequences;

- have equal opportunity to participate (including the chance to challenge, question, refute and reflect and to hear others do the same); and

- be able to accept an informed, objective, and rational consensus as a legitimate test of validity.

Such conditions will help adult learners become critically reflective of the meaning perspectives. They arrive at a higher level of development and advanced meaning perspectives. At such a stage of development a perspective is based upon complete information, free from coercion and open to alternative perspectives. It is also open to accept others as equal participants in discourse, objective and rational, 
critically reflective and able to accept an informed and rational consensus as the authority for judging conflicting valídity claims (Mezirow, 1991b).

Interpretive (or communicative) learning in Habermas theory involves social norms. 'The focus here is on people, what they are and how they relate, on symbolic interaction, on society and social history' (Jesson \& Newman, 2004). Mezirow (1991b) explains that this communicative action allows us to relate to the world around us, to other people, and to our own intentions, feelings, and desires'. While this communicative action is taking place, a specific meaning emerging from a tacit consensus agreed upon between members of a particular group - is being scrutinised for validity claims (Giddens, in Bernstein, 1985, cited in Mezirow, 1991a). Mezirow (Mezirow \& Associates, 2000) explains:

understanding in communicative learning requires that we assess the meanings behind the words; the coherence, truth, and appropriateness of what is being communicated; the truthfulness and qualifications of the speaker; and the authenticity of expressions of feelings. That is, we must become critically reflective of the assumptions of the person communicating.

Mezirow further explains that while in instrumental learning, all action is judged by its technical success in meeting the actor's objectives (e.g. use a teaching tactic that results in children learning); in communicative learning, one judges by one's success in coming to an understanding concerning the issue at hand. Thus "learning may involve a transformation in frame of reference in either of the [two] domains', explains Mezirow (Mezirow \& Associates, 2000 ).

The third area of human interest according to Habermas is the emancipatory". The emancipatory interest is what challenges distorted meaning perspectives through a process of self-reflection. Thus, what distinguishes emancipatory knowledge from the other two knowledge sources is its origin from critical selfreflection, thus it is knowledge which is appraisive rather than prescriptive or designative' (Mezirow, 1991a). This domain helps us understand the psychological and cultural assumptions that constrain the way we see the world and this influences the way we think, feel and act.

Emancipatory knowledge acts on forces which include the misconceptions, ideologies, and psychological distortions entrenched from prior knowledge 'that produce or perpetuate unexamined relations of dependence. Habermas sustains that emancipatory interest has as its major constituent element 'critical reflection". Thus, emancipatory knowledge involves an interest in self-knowledge. Such selfknowledge, which comes as a result of self-reflection and self-awareness, emancipates us through awareness of the origins and reasons behind our problems, a step towards achieving rational control over our lives. Therefore this form of learning is metacognitive in nature because "we learn not only to see the world more clearly but also to see ourselves seeing the world' (Jesson \& Newman, 2004).

Mezirow (1996; Mezirow \& Associates, 2000) explains that transformation theory views this third domain as pertaining to both instrumental and communicative learning domains. Mezirow renames this 'domain' as reflective discourse 
- that specialized use of dialogue devoted to searching for a common understanding and assessment of the justification of an interpretation or belief' (Mezirow \& Associates, 2000).

\section{Main concepts of transformative learning theory}

What follows is a discussion of the main concests underlymg the theory of transformative learning as expounded by Mezirow. In the discussion above we saw how these conceptualisations emerge in the work of three important thinkers whose work influenced philosophical and sociological thought in the last few decades. Mezirow's theory, grounded in these traditions, espouses a process of transformation, which leads the learner from a moment of disorientation to a moment of transformative self-reflection that results in a perspective transformation.

\section{Disorienting dilemma}

The 'disorienting dilemma' was one of Mezirow's original findings. In his seminal work on the factors that impede or facilitate women's progress in re-entry programmes for women, after a period away from formal education or the workforce, Mezirow assigned a disorienting dilemma as one of the major phases that such adult learners go through in their 'personal transformation".

Taylor and Elias (2012) define a 'disorienting dilemma' as 'experiences [that] illuminate and challenge heretofore invisible and urquestioned assumptions that determine how we know ourselves and the world around us?. Mezirow believes that a 'disorienting dilemma' is triggered by a life crisis or a major transition. It causes a personal transformation, which later was revised to perspective transformation (Imel, 1998). Boyd (1989) argues that for transformation to be possible, 'the resolution of a personal dilemma and the expansion of consciousness' would need to result in greater personality integration. According to Boyd and Myers (1988), a major critical phase that can be considered as a disorienting dilemma is grieving. Grieving takes place when an individual realises that old patterns or ways of perceiving are no longer relevant ${ }^{3}$ (Imel, 1998). Such a disorientation would move the agent 'to adopt or establish new ways, and finally, integrates old and new patterns' (Inel, 1998). According to Mezirow (1978b), such dilemmas 'cannot be resolved by simply acquiring more information, enhancing problem solving skills, or adding to one's competencies', but through 'a learning process by which the subject moves from an unexamined way of thinking to a more examined and critical reflective way' (Mezirow, 1999). Clark (1993a), in her study on the impact of context on the process of perspective transformation, suggests that a trigger can go beyond a single moment or a single emotion. It can be caused by what she calls 'integrating circumstances'. Integrating circumstances are defined as 'inderinite periods in which the persons consciously or unconsciously search for something which is missing in their life; when they find this missing place, the transformation process is catalysed. 


\section{Perspective transformation}

Perspective transformation is the process of becoming critically aware of how and why our presuppositions have come to constrain the way we perceive, understand, and feel about our world; of formulating these assumptions to permit a more inclusive, discriminating, permeable, and integrative perspective; and of making decisions or othenwise acting upon these new understandings (Mezirow \& Associates, 1990).

In his seminal work on wornen returning to college (1978a; 1978b), Mezirow identified 10 phases in the process of transtormative learning (see Table 2). He originally contended that they follow a linear though not always step-wise process (Taylor, in Mezirow \& Associates, 2000). Other studies (Coftrnan, 1989; Elias, 1993; Holt, 1994; Laswell, 1994; Neuman, 1996; Saavedra, 1995; Taylor, 1994, all cited in Mezirow \& Associates, 2000) show the process of perspective transformation to be more recursive, evolving, and spiralling in nature" (Taylor, in Mezirow \& Associates, 2000). Yet another 'correction' to the original 10-phase process came from Coffinan (1989, cited by Taylor, in Mezirow \& Associates, 2000) who suggested that the second phase in Mezirow's process 'should be replaced with more inclusive feelings of intense surprise, not just limited to feelings of guilt or shame' (Taylor in Mezirow \& Associates, 2000). Morgan (1987, cited in Taylor, 1997) claims that the 'most universal and profound stage' is 'anger'. This intense feeling of anger, claims Morgan, needs to be resolved before the participant can move on.

Table 2: Mezirow's 10 phases of transformative learning

Phase 1 A disorienting dilemma

Phase 2 A self-examination with feelings of guilt or shame

Phase 3 A critical assessment of epistemic, sociocaltural, or psychic assumptions

Phase 4 Recognition that one's discontent and the process of transformation are shared and that others have negotiated a similar change

Phase 5 Exploration of options for new roles, relationships, and actions

Phase 6 Planning of a course of action

Phase 7 Acquisition of knowledge and skills for implementing one's plans

Phase 8 Provisional trying of new roles

Phase 9 Building of competence and self-confidence in new roles and relationships

Phase 10 A reintegration into one's life on the basis of conditions dictated by one's perspective

Therefore perspective transformation is a recursive, spiral (Taylor, in Mezirow \& Associates, 2000) and cumulative process (Pope, 1996, cited in Taylor, in Mezirow \& Associates, 2000) that spreads over a period of time, "whereby many meaning schemes change over time culminating in a perspective transformation? 
(Taylor, cited in Mexirow \& Associates, 2000). Mezirow (Mezirow \& Associates, 1990) also posits that perspective transformation may take place on a personal, individual level; a group or/and collectively, such as what happens in widespread movements.

In Taylor's review of the research on transformative learning theory (Mezirow \&. Associates, 2000), Taylor points to the possible regressive aspect of transformation. In the joumey of transformation one needs to explore the process of change over a number of years and how an individual who has responded to a transformative experience would, in a particular moment in time regress to a previous stage of behaving and acting.

In his 1991 review of his 10-phase process, Mezirow suggests another phase between phases eight and nine, "renegotiating relationships and negotiating new relationships' (Baumgartner, 2012). Mezirow also emphasised the importance of critical self-reffection, and the constructivist assumptions that "meaning is individualistic and found inside oursetves" (Kitchenham, 2008) and that personal meanings that we attribute to our experience are acquired and validated through human interaction and communication (Mezirow, 1991b). Thus, while social interaction and social goals formed a part of Mezirow's earlier exposition, Baumgartner (2012) explains that it was only later, as a response to critiques of his work, that he expanded his theory to include with more emphasis the role of social transformation and social action as the essential objective of all transformative learning' (Mezirow, 199lb).

\section{Critical reflection and critical self-reflection}

Freire influenced Mezirow's conceptualisation of critical self-reflection through his understanding of conscientisation. Conscientisation, as discussed earlier, comes about through the process of developing critical awareness. Such critical awareness leads educators to get past what he calls 'instilled certainty', which prohibits one from moving away from the status quo and transform practice to affirm the needs of the students.

As mentioned earlier, Freire refers to the three stages of 'consciousness growth', which culminates in critical thought (Shor, 1993). The lowest is "intransitive thought' (when one feels that one's life is out of control and that change is beyond one - it's up to fate or God); next comes 'semitransitive' (this stage involves some thought and action for change - addresses one problem at a time and as they occur, thus not seeing the global view - lacks complexity - follows a leader); and finally 'critical transitivity' (at this stage someone thinks globally and critically about their present condition and decides to take action for change).

Mezirow expounds on this latter stage to inform the main notions that form his theory (disorienting dilemma, critical consciousness, critical reflection, critical self-reflection on assumptions, and critical discourse) (Mezirow, 1978a; 1978b; 1985).

According to Mezirow (1991b; 2012; Mezirow \& Associates, 2000) critical selfreflection can bring about transformation of a frame of reference that comprises 
habits of mind and subsequent points of view. A habit of mind is a set of assumptions that are broad, generalised orienting predispositions that act as a filter for interpreting the meaning of experience (Mezirow \& Associates, 2000). Mezirow (1991b) originally highlighted three habits of the mind: epistemic (knowledge of how a person uses acquired or possessed knowledge); sociolinguistic (how one uses language in a social setting); and psychological (how people perceive themselves). Later, in Learning as Transformation: Critical Perspectives on a Theory in Progress (2000), he lists a variety of perspectives such as moral-ethical (conscience and moral norms); philosophical (religious doctrine, philosophy, transcendental world view); and aesthetic (values, tastes, attitudes, standards, and judgement about what is beautiful, sublime and ugly).

Critical self-reflection leads to four types of learning (or transformation); learning through elaborating existing frames of reference; learning new frames of reference; learning through transforming habits of the mind and finally learning through transforming points of view. It is to be noted that an individual can change a point of view 'by trying on another's point of view' (Mezirow \& Associates, 2000). But, according to Mezirow, a person cannot try on someone else's beliefs (or habit of mind). Thus, while as an educator or trainer someone can aspire to change someone else's point of view through sharing of good practice, transformation of a habit of mind needs to come from within learners themselves.

Mezirow expounded on this active notion of critical reflection and proposed three types of reflection: content reflection, process reflection and premise reflection. The first two types lead to what Mezirow calls straightforward transformation - transformation which results from asking questions about 'what was done in the past' and 'considering actions' origins and related factors' (Kitchenham, 2008). The third type of reflection leads to more profound transformation, premise reflection, which is achieved through considering the larger picture.

In the latter type of reflection people evaluate their own value system, that which underlies their actions to question the basic premise of their actions. Such action will lead to a more comprehensive and global re-evaluation of someone's practice (transformation of meaning perspective). The previous two stages bring about a change in a single meaning scheme.

Oyer the years, Mezirow continued to refine his understanding of critical reflection and presented two new aspects. One was the critical reflection of assumptions, whereby the learner not only looks back on something that occurred but also examines the assumptions or presuppositions that were involved in the reflection process' (Kitchenham, 2008). 'The other aspect was that related to the concept of critical self-reflection of assumptions. This involves a critique of a premise upon which the learner has defined a problem' (Mezirow, 1998, cited in Kitchenham, 2008). Thus, the latter notion is akin to what Mezirow earlier referred to as premise reflection in which "learners examine their worldview in light of their own particular belief or value system' (Kitchenham, 2008). 


\section{Conclusion}

The discussion above focused on the process of transformation as amplified by Jack Mezirow in his theory of transformative learning. Here we explored the different phases which an adult leamer goes through when seeking to learn and thus goes through a transformative learning experience.

This paper underscores those factors that help bring about both personal and professional transformative learning. This paper emphasised that transforma * tive learning is a mutually intercependent experience. Individual transformation amounts to, and is influenced by, the collective transformation.

Habermas' influence on Mezirow's work has highlighted the importance of a shared language of possibility. Through a shared language, a learning comrnunity can create a dialogic environment through which intentions, beliefs and interventions can be shared among the professional community. This review accentuates the importance of a shared language as a means of articulating a change in perspective.

Mezirow's contribution to adult learning theory reviewed in this paper shows the richness and complexity of aduit learning. Adult learning goes beyond acquisition of knowledge; it transforms action and in turn transforms the community in which learning takes place.

\section{References}

Argyris, C., \& Schon, D. (1974). Theory in Practice: Increasing Professional Effecriveness. San Francisco, CA: Jossey-Bass.

Baumgartner, L. M. (2012). Mezirow's theory of transformative learning from 1975 to present. In E. W. Taylor, P. Cranton, \& Associates, The Handbook of Tronsformative Learning: Theory, Research, and Practice (pp. 99-115). San Francisco, CA: Jossey-Bass.

Belzer, A. (2004). 'It's not like normal school': The role of prior learning contexts in adult learning. Adult Education Quarterly, 55(1), 41-59.

Boud, D., Keogh, R., \& Walker, D. (Eds) (1985). Reflection: Turning Experience into Learning. New York, NY: RoutledgeFalmer.

Bowers, C. (1984). The Promise of Theory: Education and the Politics of Cultural Change. New York, NY: Longman.

Boyd, R. D. (1989). Facilitating personal transformation in small groups: Part I. Small Group Behaviour, 20(4), 459-474.

Boyd, R., \& Myers, J. G. (1988). Transformative education. International Joumal of Lifelong Education, 7(4), 261-284.

Brookfield, S. (1987). Developirtg Critical Thinkers: Challenging Adults to Explore Alternative Way's of Thinking and Acting. San Francisco, CA: Jossey-Bass.

Burke, R., \& VanKleef, J. (1997). Prior learning assessment in Canada: A credit to workforce development. Career Planning and Adult Developntent Journah 12(4), 23-28.

Calleja, C., \& Borg, C. (2014). Teacher Transformation Through a Professional Changing Experience: The Let Me Learn Professional Learning Process. Paper presented at the Interuational Teacher Education Conference. Dubai, United Arab Emirates. 
Caswell, R. L. (2007). Teacher transtormation achieved through participation in the national writing project's invitational summer institute. (Unpublished doctorial dissertation). Kansas.

Challis, M. (1996). Andragogy and the accreditation of prior learning: Points on the continuum or uneasy bedfellows? International Joumal of Lifelong Education, 15(1), 32-40.

Clark, C. M. (1993a). Chonging Course: Initiating the Transformational Learning Process. 34th Annual Adult Education Research Conference - Proceedings (pp. 354-361). Pennsylvania State University.

Clark, C. M. (1993b). Transformational learning. In S. B. Merriam (Ed.), An Update on Adult Learning Theory. (Vol. 57, pp. 47-56). San Francisco, CA: Jossey-Bass.

Collard, S., \& Iaw, M. (1989). The limits of perspective transformation: A critique of Mezirow's theory, Adult Education Quarterly, 39, 99-107.

Cranton, P. (2013). Transformative learning. In P. Mayo (Ed.), Leaming with Adult: A Reader (pp. 267-274). Rotterdam, Netherlands: Sense Publications.

Cranton, P., \& Taylor, E.W. (2012). Transformative learning theory: Seeking a more unified theory. In P. Cranton, E. W. Taylor, \& Associates, Handbook of Transformative Learning. Theory, Research, and Practice. San Francisco, CA: Jossey-Bass.

Elias, $_{3} \mathrm{D}$. (1997). It's time to change our minds: An introduction to transformative learning. ReVision, $20(1)$, pp. $2-6$.

Freire, P. (1970). Pedagogy of the Oppressed, New York, NY: Herter and Herter.

Freire, P. (1974). Education for Critical Consciousness (Reprinted in 2007 ed.). London, UK: Continumm.

Frejre, P. \& Faundez, A. (1989), Learning to Question: A Pedagogy of Liberation. Geneva, Switzerland: World Council of Churches.

Habermas, J. (2971). Krowledge and Human Interest. Boston, MA: Beacon.

Habermas, J. (1984). The Theory of Communicative Action: Reason and the Rationalization of Society. Boston, MA: Beacon.

Habermas, J. (1987). The Theory of Communicative Action - Lifeworld and System: $A$ Critique of Functionalist Reason. Boston, MA: Beacon.

Habermas, 5. (1989-90 Fall/Winter). Justice and solidarity: On the discussion concerning 'stage 6'. The Philosophical Forum, XXI(1-2), pp. 32-51.

Hart, C. (1998). Doing a Literature Review. Thousand Oaks, CA: SAGE Publications.

Horster, D. (1992). Habermas: An Introduction. (H. Thompson, Trans.) Philadelphia, PA: Pennbridge Books.

Imel, S. (1998). Transformative learning in adulthood. ERIC Digest (200).

Jesson, I. G., \& Newman, M. (2004). Radical adult education and learning. In F. Griff, \& F. Griff (Eds), Dimensions of Adult Learning: Adult Edecation and Training in a Global Era. Crows Nest, NSW, Australia: Allen \& Unwin.

Kasi, E. \& Yorks, L. Y. (2002). An extended epistemology for transformative learning theory and its application through collaborative inquiry. Teachers College Record, 2 January, 1-17.

Kitchener, K., \& King, P. (1990). The reflective judgment model: Transforming assumptions about knowing. In J. Mezirow \& Associates, Fostering Critical Reflection in Adulthoou: $A$ Guide to Transformative and Emancipatory Learning (pp. 157-176). San Francisco, CA: Jossey-Bass.

Kitchentram, A. (2008). The evolution of John Mezirow's transformative learning theory. Journal of Transformative Education, 6, 104-122.

Knowles, M. (1998). The Adult Learner: The Definitive Classic in Adult Educntion and Finman Resources Development. Houston, TX: Gulf Publishing. 
Kreber, C. (2012). Crítical reflection and transformative learning. In Ev W. Taylor, P. Granton, \& Associates, The Handbook of Transformative Learning: Theory, Research, and Practice (pp. 323-341). San Francisco, CA: Jassey-Bass.

Kuhn, T. S. (1962). The Structure of Scientific Revolutionts. Chicago, IL: University of Chicago Press.

Lyytinent, K., \& Hirschheims, R. (1988). Information systens as rational discourse: An application of Habermas' theory of communicative action. Scandiravian Journal of Management, 4(1-2), 19-30.

MacIsaac, D. (1996). The critical theory of Jurgen Habermas. Retrieved 21 February 2013 from: http://physicsed.buffalostate.edu/danowner/habcritthy,html

Marsick, $\mathrm{V}$, \& Mezirow, J. (2002). New work on transformative learning. Teachers College Record, 25 Ianuary.

Merriam, S. B., \& Caffarella, R. S. (1999). Learting in Adulthood. San Francisco, CA: Jossey-Bass.

Mezirow, J. (1978a). Education for Perspective Transformation: Women's Re-entry Prograns in Community Colleger. New York, NY: Teachers College, Columbia University.

Mezirow, J. (1978b). Perspective transformation. Adult Education (28), 100-110.

Mezirow, J. (1981). A critical theory of adult learning and education. Adult Education Quarterly, 32(3), 3-24.

Mezirow, J. (1985). A critical theory of self-directed learning. In S. Brookfield (Ed.), Selfdirected Learning: From Theory to Practice (New Directions for Continuing Education, 25). San Francisco, CA: Jossey-Bass.

Mezirow, J. (1989). Transformation theory and social action: A response to Collard and Law. Adult Education Quatterly, 39(3), 169-175.

Mezirow, 1. (1991a). Transformative Dimessions of Adult Learning. San Francisco, CA: Jossey-Bass.

Mezirow. J. (1991b). Transformation theory and cultural context: A reply to Clark and Wilson. Adult Edrication Quarterly 41(3), 188-192.

Mezirow, J. (1996). Beyond Freire and Habermas: Confusion. A response to Bruce Pietrykowski. Adult Education Quarterly, 46(4), 237-239.

Mezirow J. (1997). Transformative learning: Theory to practice. New Ditections for Adult and Continuing Education, 74, 5-12.

Mezirow, J. (1999). Transformation theory - Postmodern issues. Retrieved 20 February 2013 from: www.adulterc.org/Proceedings/1999/99mezirow.htm

Mezirow, J. (2012), Learning to think like an adult: Core concepts of transformation theory, In E. W. Taylor, P. Cranton, \& Associates, The Handbook of Transfornative Learnin:: Theory, Research, and Practice (pp. 73-95). San Francisco, CA: Jossey-Bass.

Mezirow, I. \& Associates. (1990), Fostering Critical Reflection in Adulthood. San Francisco, CA: Jossey-Bass.

Mezitow, J.s \& Associates (2000). Learnitg as Transformation: Critical Perspectives on a Theory in Progress. San Francisco, CA: Jossey-Boss.

Romaniuk, K., \& Fern, S. (2000). Enhancing employability: The role of prior learning assessment and portfolio. Journal of Workplace Learming, 12(1), 29-34.

Shor, I. (1993). Education is politics: Paolo Freire's critical pedagogy. In P. MacLaren, \& P. Leonard (Eds), Paolo Freire: A Critical Encounter (pp. 23-35). New York, NY: Routledge.

Taylor, E.W. (1997). Building upon the theoretical debate: A critical review of the empirical studies of Mezirow's transformative learning theory. Adult Education Quarterly, 48(1), 34-59. 
Taylor, E. W. (2000a). Analyzing research on transtormative learning theory. In I. Mezirow; \& Associates, Learninty as Transformation Critical Perspectives on a Theory in Progress. San Francisco, CA: Jossey-Bass.

Taylor, E.W. (2000b). Fostering transformative learning in the adult education classroom. The Canadian Toumal of the Strdy of Adult Education, 14, 1-28.

Taylor, E. W. (2009). Fostering transformative learning. In J. Mezirow, E. W. Taylor, \& Associates, Transformative Learning in Practice: Insights from Conmunity: Workplace, and Higher Education (pp. 3-17). San Francisco, CA: Jossey-Bass.

Taylor, K, \& Elias, D. (2012). Transformative learning: A developrnental perspective. In E. W. Taylor, P. Cranton, \& Associates (Eds.), The Fandbook of Transformative Learning: Theory, Research, and Practice (pp. 147-161). San Francisco, CA: Jossey-Bass.

Taylor, E. W, \& Snyder, M. I. (2012). A critical review of research on transformative learning theory, 2006-2010. In E. W. Taylor, P. Cranton, \& Associates, The Handbook of Transformative Learning: Theary, Research, and Pratice (pp. 37-55). San Francisco, CA: Jossey-Bass. 